Island Studies Journal, Vol. 9, No. 1, 2014, pp. 23-42

\title{
Managing migration, scaling sovereignty on islands
}

\author{
Jenna M. Loyd \\ University of Wisconsin-Milwaukee, Milwaukee, WI \\ USA \\ jloyd@uwm.edu \\ and \\ Alison Mountz \\ Wilfrid Laurier University, Waterloo, ON \\ Canada \\ amountz@,wlu.ca
}

\begin{abstract}
Island and maritime spaces between regions have become central places of recurrent crises over human migration and re-articulations of state sovereignty. Islands, the very sites where land meets water, are among the contested sites of struggle over entry and exclusion. In this paper, the Mediterranean is our main area of geographical inquiry. We explore the connections between crises of sovereignty, migration and islands, seeking to enhance connections between scholarship on migration and sovereignty. We argue that migration management and its geographical articulation on islands involve persistent reconfigurations of sovereignty, particularly evident during times of crisis over human migration. Such crises and re-articulations of sovereignty are creative uses of geography that repeatedly lead to a failure to protect human rights. To develop this argument, we bring feminist theorists of state sovereignty into conversation with political geographers. We move across scales of governance and political mobilization to show how a reconfiguration of sovereignty through regional and national management regimes leads to complex legal geographies and sovereign entanglements that migrants and advocates must navigate to claim rights.
\end{abstract}

Keywords: feminist geography; islands; migration management; sovereignty; territoriality

(C) 2014 - Institute of Island Studies, University of Prince Edward Island, Canada.

\section{Introduction}

Border walls have become paradigmatic symbols and material manifestations of the efforts of nation-states to regulate and deter irregular migrants and asylum seekers. Moreover, fences and their associated surveillance technologies are accompanied by policing and boundary enforcement efforts in locations that are increasingly distant from and external to the territorial boundaries of any given state. Many scholars have argued persuasively that walls do not work to keep people from entering sovereign territory (Brown, 2010; Dear, 2013). Enforcing sovereign territory in places that are fluid, such as in the Mediterranean or Aegean seas, highlights not only the deep limitations of border walls, but also the paradoxical positions of islands as places of interconnection and exclusion, and the sea as a medium of connection and deterrence. 
In regions divided sharply by wealth and power, the island and maritime spaces between regions have become central places of recurrent crises over human migration and rearticulations of state sovereignty. This paper explores the connections between crisis, migration and islands, and seeks to enhance connections between scholarship on migration and sovereignty. State sovereignty is perpetually shifting as it is re-articulated across time and space through human movement and migration policing. New articulations of sovereignty often transpire in times construed as crises. In other words, the limits of sovereignty are exposed when people leave northern Africa or Syria en masse, fighting for their lives; but these moments are also the occasion for the production of crisis, which enables politicians and other state agents to advance particular political agendas and practices (Bigo, 2002; Mountz, 2010).

States and state actors are not alone in their efforts to assert control over mobility in peripheral zones. Activists, military personnel, fishers, captains, attorneys, non-governmental organizations (NGOs), supra-state agencies, and migrants themselves attempt to assert their agency and mobility in these transitional zones between states. In so doing, they negotiate the terms of safety, safe haven, legality, human rights, and political asylum, as well as the evershifting locations of boundary enforcement. As such, states' efforts to manage human mobility do not end struggles over territoriality, but rather complicate them. We suggest that these efforts intensify crises of state sovereignty and human rights at a range of geographic scales.

Amid the fluid spatial arrangements we discuss, 'migration management' has become a popular term to encapsulate the ways in which nation-states seek to implement and coordinate regional migration and refugee policies (see Betts, 2010). These regional level experiments with sovereignty have emerged at a particular historical moment in which colonial geographies are being reworked through global economic restructuring. The idea that migration can and should be managed corresponds with an overarching desire shown by states to impose order on an inherently chaotic process (Mountz, 2010; Hiemstra, 2013). Yet, the management of mobility remains at odds with the political crises and long-term ecological and economic devastations that fuel displacement and sometimes mass spontaneous migrations. These regional efforts have not created a managed terrain of migration, but increased sites of boundary enforcement and intensified scrutiny of nation-state commitments to human rights.

We argue that migration management, and its geographical articulation on islands, involves persistent reconfigurations of sovereignty, particularly evident during times of crisis over human migration. These crises and re-articulations of sovereignty are creative uses of geography that repeatedly lead to a failure to protect human rights. Islands, the very sites where land meets water, are among the contested sites of struggle over entry and exclusion (Walters 2008).

Material in this paper is drawn from the Island Detention Project, with fieldwork conducted from 2010 to 2012 on the Italian islands of Lampedusa and Sicily, the Australian territory of Christmas Island, and Guam and Saipan of the US Commonwealth of Northern Mariana Islands. Methods included semi-structured interviews, participant observation, and archival research on the development and use of detention and associated struggles over entry and exclusion that transpire on islands. These materials were supplemented by semi-structured interviews in Greece, Malta, and Indonesia and by reports conducted by human rights and legal organizations.

We organize the paper around nested scales in order to trace how crises of sovereignty are reconfiguring geographies of power and mobility. We move across scales of governance and political mobilization in order to demonstrate how the reconfiguration of sovereignty 
through regional and national management regimes results in complex legal geographies and sovereign entanglements. We begin by situating conflicts on islands within the geopolitics of migration, and then look sequentially at three particular places (and scales) - the island, the detention facility, and the migrant body - to trace how power operates through these sites. While asylum is ostensibly a determination made by states on an individual basis, in practice asylum is deeply geopolitical and the geography of asylum seeking is uneven. That is, the actual places and scales through which asylum is made possible and foreclosed upon are rapidly shifting. As struggles over sovereignty rearticulate geographies of law, power and safety, we ask who is allowed to move, who is allowed to stay, who benefits from, and who loses in the migration management paradigm.

\section{Islands and the geopolitics of regional migration management}

The principle of human rights as encoded in Geneva conventions following World War II relies on nation-states to exercise their sovereignty in the protection of human lives. Yet, the history of migration and asylum-seeking shows repeated clashes between state sovereignty and human security (Hyndman, 2008). Such discord between the regulation of mobility as an assertion of sovereign power and the desire of individuals to seek asylum continues in the contemporary field of migration. As a result, geopolitical relations repeatedly result in the restriction of access to human rights.

In the introduction to a special issue on the geopolitics of migration, Hyndman (2012, pp. 2-3) historicizes the connections among geopolitics, rights, security and migration,

If the liberal democratic discourse of human rights has proven inadequate, then the politicization of such basic provisions in the guise of 'human security' attempted to revive them as geopolitics through the 1990s and early 2000s. Just as the 'war on terror' has invented the 'enemy combatant' to replace the prisoner of war, politicized spaces have emerged to protect civilians in conflict zones. Such 'geopoliticization' of humanitarianism in relation to human displacement illustrates how the flotsam and jetsam of conflict are indeed 'extra' worries that can be sequestered spatially out of view or in between the cracks of territorial jurisdiction.

Building on Hyndman's geopolitics of migration, we reference the ways in which the relationships between states structure human migration, facilitating or inhibiting mobility with extra/territorial creativity in ways that benefit national agendas.

Since the 1980s, two primary paradigms of governance have developed to resolve crises of punctuated 'spontaneous' migrations and migrant detention: regionalization and management. Regionalization refers to the coordinated efforts of nations to manage migration at a regional level through shared policing and interception efforts, synchronizing travel and visa requirements, and pushing the boundary enforcement of and for wealthy countries onto other states. Critics have labelled the exclusionary results of these efforts 'Fortress Europe' and 'Fortress NAFTA' (Carr, 2012; Klein, 2003). These paradigms, in turn, have institutionalized crisis in new forms, at new geographic scales, and through reconfigurations of scale.

As regionalization and migration management regimes took hold over the last twenty years, islands come to the fore as significant geographic locations from which to examine struggles over migration, sovereignty and enforcement (Mountz, 2011). Islands are often 
proximate to interceptions at sea and areas of origin. Islands emerge as enforcement archipelagos in all of the regions where asylum is sought after, contested, and highly politicized. We are interested here not only in the policing of these islands and the important research in this area (e.g., Carling, 2007; Cuttitta, 2009; Mutterbeck, 2009; Andrijasevic, 2010; Mainwaring, 2012), but in the discourses surrounding the problematization of island detention and the broader crises of human migration along the margins of EU (European Union) territory. Orientalizing (Said, 1978),, neo-colonial discourses about islands and islanders themselves often enable the exploitation of place and the kinds of enforcement strategies that take place there (Kothari \& Wilkinson 2010; Bejarano et al., 2012)

The Island Detention Project (2013) examines interception and detention off the coasts of Australia, North America and the European Union. In the European Union, regionalization involved the elimination of internal borders for the purposes of labour migration. Policing was shifted to the external border of the EU where islands have played an increasingly important role in battles over entry (Mainwaring, 2012). These have included Spain's Canary Islands near the western coast of Africa, the Italian island of Lampedusa near Tunisia, as well as Malta, Cyprus and the islands of Greece. ${ }^{1}$ Marine smuggling and policing move geographically in relation to one another. As Frontex coordinated intensified policing around the Canaries and later Lampedusa in 2008 and 2009 (Carling, 2007; Andrijasevic, 2010), smugglers and migrants (and some would argue, authorities themselves) directed marine landings east to Greece and Malta (Mutterbeck, 2009; Mainwaring, 2012).

\section{Geographic scale, border walls, and the crisis of nation-state sovereignty}

Many early accounts of the social and economic trends that accompany globalization characterized the restructuring of the nation-state and state sovereignty in terms of deterritorialization whereby the 'space of flows' takes precedence over the 'space of place.' For Castells (1996), networked flows of capital and power increasingly supplant older, placebased organizations of urban life and national identity. Whether critical or celebratory, narratives of uprootedness emphasize how nation-states have grown increasingly unable to facilitate the kinds of concerted actions necessary to intervene in transnational issues such as economic transactions, global climate change, and human security. Politics and sovereignty became unmoored from the nation-state form. Accordingly, new spaces for politics implicitly are also deterritorialized and often theorized in terms of a transnational public sphere or a global civil society where everyone is entitled to human rights (Beck, 2006; Bosniak, 2000; Fraser, 2009). However, the responsibility to protect is increasingly in question, in part due to geopolitics (Hyndman, 2008).

Brown (2010) examines the vexed relationships among territoriality, state violence, and sovereignty. She focuses on the paradoxical trend that powerful states around the world are fortifying and militarizing territorial boundaries even as global capitalist restructuring and neoliberal, anti-state ideologies work against national sovereignty. Rather than conceptualizing walling as a practice of strong sovereign power, Brown argues that border enforcement illustrates a deep crisis of state sovereignty. She suggests that, faced with globalization, nationstates' increasing reliance on apparently robust, exclusionary architecture serves as a symbol of sovereign power rather than a mark of effective state practices. "As nation-state sovereignty

\footnotetext{
${ }^{1}$ Asylum seekers also attempt to claim asylum in the French territory of Mayotte. This island does not feature prominently in this paper or the Island Detention Project due to its distance from other islands in the study.
} 
wanes, states and sovereignty do not simply decline in power or significance, but instead come apart from one another" (Brown, 2010, p. 23). While sovereignty increasingly becomes the realm of capital and "God-sanctioned political violence," according to Brown (ibid.), state power is being reworked internally and externally. "Rather than iterations of nation-state sovereignty, the new nation-state walls are part of an ad hoc global landscape of flows and barriers both inside nation-states and in the surrounding postnational constellations, flows and barriers that divide richer from poorer parts of the globe" (ibid., p. 24).

We are compelled by Brown's theorization of nation-state bordering as a manifestation of crisis, and by her attention to their theatrical quality, their "staging of sovereign powers of protection" (ibid., p. 25). This theoretical insight sheds light on the predominance of high profile shows of state power on the high seas (Cuttitta, 2009; Mountz, 2010). We take pause, however, to consider how state power and state sovereignty are being reworked at a range of geographic scales. Attention to geopolitical conflicts, and the in-between spaces where migrants find themselves denied their rights (and lives), suggests that even temporary resolution of these sovereign crises reassert the power of national sovereignty.

To develop this argument, we turn to scholarship in geography on the socio-political construction of geographic scale (Marston, 2001; Herod, 2011) and reworking of nation-state sovereignty (Agnew, 1994). Scale is not a pre-given series of nested hierarchies and associated spaces, but instead a result of struggles over power, place, and meaning making. The restructuring of the nation-state has drawn clearest attention to the gap between sovereignty and territory; nations cannot be understood as discrete territorial units (Agnew, 1994). Even in the midst of tremendous flux over the regulatory and social welfare functions of nation-states, nation-states retain and reinforce the sovereign claim to govern entry to territory and the rights that ensue to citizens and residents.

Transnational migration and crises over asylum, in particular, show that the partial unmooring of democratic politics from the nation state (deterritorialization) should not obscure the 'concomitant reterritorialization to deterritorialization, where new geographies, maps, and territorial configurations are emerging' (Elden, 2009, p. xxviii). Migration crosses thresholds of sovereign territory and challenges the primacy of national allegiances. Yet, shifting politics beyond the national frame does not simultaneously resolve the dominance of such a politics of territoriality. Furthermore, shifting enforcement offshore results in complex struggles over jurisdiction, governance, and legality (Baldacchino \& Milne, 2006).

In the dialectic of deterritorialization and reterritorialization, the construction of scale is one means through which political contests over migration emerge. Islands provide a spatial lens through which to examine this rescaling of sovereignty. Mobility, citizenship, and claims to belonging are regulated at the national scale, particularly at sites where the state territorializes itself through bordering practices. Individuals alone cannot resolve their claims to move or belong and must instead rely on the state system. Those caught in territories between states are among the most marginalized to assert their rights to move, stay, or belong.

Feminist geographies of migration, moreover, have drawn attention to the transnational, geopolitical, and interstitial spaces of migration (Silvey, 2004; Hyndman \& Giles, 2011; Mountz, 2011). Feminist scholarship on migration has been interested in tracing the interrelationships between gendered embodiment and gendered policies regulating migration as well as developing methods that can challenge dominant, masculinist discourses framing migration. These discourses include state-centrism, the privileging of interstate and geopolitical relations and perspectives, and economic policies that ignore the value of social 
reproduction. Thus, one of the principles that holds these feminist works together is their attention to finer scale analyses that privilege embodied experience and the creative construction of relational space that migrants, their advocates, and allies create to mitigate human rights abuses and foster human freedom (Hyndman, 2008; Coddington, Catania, Mitchell-Eaton, et al., 2012). Such experiences and expressions of human agency tend to be absent from or represented through the perspective of state-centered understandings.

The irreconcilable interdependence of human rights and state sovereignty become most evident in sites where people are held against their will or prevented from moving freely. These clashes in part constitute the boundaries of the region, cohere on the grounds of islands, institutionalize crisis through detention (Agamben, 1998), and are animated by people's ongoing attempts to move, reside, and work freely and safely. Nation-states and carceral facilities are inherently unstable forms whose legitimacy must constantly be renewed; this need perpetuates states and infrastructures of crisis and exceptionalism (Hall, Critcher, Jefferson, et al., 2013). Movement across scales thus reveals a variety of political agendas at work on the bodies politic and the bodies of migrants. To illustrate our claims, we focus on islands as places where crises of sovereignty and the reterritorialization of politics take place.

\section{Migration by sea, crisis, and the construction of regional enforcement regimes}

Most migrants travelling by boat en route to other sovereign territories make asylum claims once they have been intercepted. These asylum claims rely on the architecture of the $1951 \mathrm{UN}$ Convention Relating to the Status of Refugees and its 1967 Protocol, which signatory states agree to observe and implement. But the scales through which states assert sovereign power to protect are slippery, as evident when the problem of migration at sea can be framed and reframed as the problem of another country or region. These scalar shifts can be sovereign moves away from responsibilities of states to protect and toward the shirking, deferring, or contracting out of responsibility to protect human rights and human lives. These negotiations often lie at the heart of struggles over territorial control at sea. Who will respond, who will protect, who will push back or refuse entry, and who will provide shelter? How do states impose their own expressions of sovereignty or interests on other states and people by restricting human mobility? Often, such arrangements and conflicts therein are worked out through regional solutions (Marchetti, 2010).

Regional 'solutions' long have been spatial arrangements that capitalise on geopolitical fields of power designed to keep people closer to their regions of origin (Hyndman \& Giles, 2011). In the early 1980s into the 1990s, the United States implemented an interdiction and detention policy intended to deter migration across the Caribbean Sea by boat. In the 1990s, the practice commonly became referred to as the 'wet-foot, dry-foot' policy. Migrants who reach land (dry foot) have the ability to seek asylum, whereas those intercepted at sea are more likely to be returned or detained offshore. A similar practice ensued off the northern coast of Australia where the Tampa Incident gained international notoriety. In 2001, Prime Minister John Howard refused to allow the Tampa, a Norwegian ship that rescued 433 Middle Eastern asylum-seekers, to enter Australian territorial waters. Crisis at sea engendered a shift in policy known as Australia's Pacific Solution. The 'solution' denied access to the asylum process on mainland Australian territory, instead essentially contracting out the processing and detention of asylum seekers to detention facilities on islands within the national territory (such as Australia's Overseas Territory of Christmas Island) or even beyond, in Papua New Guinea's 
Manus Island, and Nauru. The Pacific Solution gave way to what have been referred to more recently as the Indian Ocean, Indonesian and Malaysian solutions (Marr, 2009). Similarly, Lampedusa and Malta have served as platforms for regional solutions in the Mediterranean.

The United States' and Australia's practices provided a context for regional 'best practices' that could inform regional solutions in the Mediterranean (Goodwin-Gill, 2011). Italy in 2007 implemented its policy of respingimento, pushing back vessels suspected of carrying undocumented migrants (European Commission, 2005, p. 59, Andrijasevic, 2006; Cuttitta, 2009; Klepp, 2010). This more aggressive interception denied potential asylum claimants access to sovereign Italian territory by refusing their entry into territorial waters and facilitated return to and detention in North Africa. Enabling this shift in policy were bilateral arrangements for return from Italy to Libya and Algeria. Migrant travel at sea has always involved tense negotiations among neighbouring territories. In the case of Italy and other routes to the EU, when intensified policing shuts down one route, migrants will seek out others (Triandafyllidou, this issue) The number of migrants arriving in Italy by boat from North Africa was 19,900 in 2007, and then 36,000 in 2009 (UNHCR, 2009, cited in Frelick, 2009: 19). Subsequently, as Frontex intensified policing of the Mediterranean in 2008 and 2009 (Carling 2007; Triandafyllidou, this issue; Mountz \& Loyd, forthcoming, 2014), the numbers of maritime arrivals on Greece and Malta increased, causing diplomatic tensions between states and perilous journeys and legal limbo for migrants (Lutterbeck, 2009, p. 119).

Another notorious case of territorial struggles involving land and water played out around the margins of the EU in April 2009 when the captain of the Pinar E rescued 140 migrants from a vessel in distress. Like the captain of the Tampa, the Captain of the Pinar E, a Turkish freighter, sought to disembark at the nearest port, which was Lampedusa. Italy argued that the interception occurred within the search and rescue zone administered by Malta, whereas Malta maintained that the ship should travel to the nearest port. The stand-off continued for four days until the President of the European Commission appealed to both countries for a solution, and Italy accepted the migrants (Frelick, 2009, p. 38). When over 350 people drowned off the coast of Lampedusa in October 2013, Italian authorities were criticized for the length of time it took them to respond to a ship in distress within plain sight (BBC News Europe, 2013; de Haas, 2013a).

At the scale of the region and on those island territories involved in migration struggles, both contests and alliances emerge between nations engaged in shared migration management and border fortification. In the Pinar E example, Italy and Malta bickered over the extent of sovereign responsibility at sea, contrary to EU discourses of policy harmonization and collaborative policing coordinated by Frontex. The regional scale grows unstable in its periphery: in international waters, EU-supported detention facilities in Libya, and the layering of external boundaries (cf. Frontex vis-à-vis EU).

The region also remains internally divided as individual nation-states and regional bodies come into conflict over states' responsibilities to carry out regional policy agreements (Bialasiewicz, Dahlman, Apuzzo, et al., 2009). This is especially evident in the case of migration to and through Greece. The January 2011 ruling by the European Court of Human Rights, in the case of M.S.S. v. Belgium and Greece, found that Greek detention practices routinely violated the European Convention on Human Rights prohibition against torture and inhuman and degrading treatment (M.S.S. v. Belgium and Greece, 2011). The court also found that Belgium had violated its human rights obligations by returning an Afghan asylum seeker to Greece. Conflicting EU sovereignties clashed again in 2010 when Frontex deployed 175 
border guards to Greece's boundary with Turkey and facilitated the detention of migrants and asylum seekers in inhumane conditions in Greece. Given the 'absolute prohibition on torture and inhuman and degrading treatment,' Human Rights Watch (2011) demanded that Frontex suspend operations that result in migrant detention in Greece. The organization also recommended using facilities 'elsewhere in the Schengen area where conditions were compliant with EU standards' (2011, p. 51).

Like migrants themselves, these geopolitical struggles over territorial control at sea eventually reach land. There, a new range of negotiations over status and access to asylum take hold as states attempt to shirk responsibility to protect. Whereas crises - and responses to crises - resolve some issues, a frequent result is the prolonged vulnerability for migrants who find themselves at the centre of international struggles over enforcement. Nowhere are these dynamics more pronounced than on those islands that emerge as hot spots during transnational journeys at sea (Mountz, 2011). The dominant geographical imagination suggests that islands offer opportunities to control, contain, and detach migrants far from mainland populations.

\section{The scaled space of islands}

The sheer array of people working in response to human migration on small island territories suggests the contested nature of migration and detention there. During field research in 2010 and 2011 on the very small island of Lampedusa (with a land area of $20.2 \mathrm{~km}^{2}$ ), we encountered local activist groups working alongside Italian military personnel and international NGOs including the Red Cross, Save the Children, Médecins Sans Frontières, the United Nations High Commissioner for Refugees, and the International Organization for Migration, among others. Each organization was motivated by and worked under the rubric of competing missions and narratives to rescue, protect, serve, manage, advocate, enforce, and secure.

The island of Lampedusa has played a prominent role in struggles over entry to the EU of African migrants fleeing persecution, conflict and political instability that intensified during the Arab Spring of 2011. Migrants entering the EU by sea from Africa come from a range of countries and regions, including Eritrea, Senegal, Gambia, Sierra Leone, Liberia, Mali, Côte d'Ivoire, Ghana, Nigeria, the Democratic Republic of Congo, Cameroon, Sudan, the Horn of Africa, Syria, and even Asia (de Haas, 2006). After peaking in 2008, boat arrivals on Lampedusa had all but disappeared - or were under-reported in official statistics - by summer 2010, when we first arrived due to the push-back policy of Italy, formal agreements between Italy and Libya, and significant investment of resources from Italy to Libya. Landings continued in other parts of Sicily and mainland Italy. During the summer of 2010, the detention centre on Lampedusa remained mostly empty.

After a relatively quiet time on Lampedusa in 2010 with almost no boat landings officially recorded, the Arab Spring that began in Egypt and spread quickly to neighbouring states in the early months of 2011 prompted the departure of many migrants from northern Africa and a quick succession of arrivals on the island. Due to the rough seas surrounding Lampedusa, ships of any kind are often unable to arrive for weeks at a time. Then, when the seas clear, a series of ships will arrive in quick succession, intensifying the atmosphere of crisis. By mid-February, Frontex reported that 5,000 migrants had arrived on Lampedusa. In March 2011, some 3,000 migrants were reported to be sleeping on the docks (Global Detention Project, 2012). International attention again turned to a detention facility and a political setting with an unstable relationship to the European human rights community. Lampedusans found 
themselves in the international news cycle once again with the collision of geopolitical and local events. By the end of February, what had very recently been an empty facility slated for closure erupted in a series of confrontations. Migrants threatened hunger strikes and set fire to the centre, prompting announcement of closure of the port, deemed unsafe (Global Detention Project, 2012). The Italian national government declared a state of emergency (Cole, 2011), and some detainees were not allowed to leave what was once an open detention centre. Lampedusa Mayor De Rubeis weighed in on the crisis,

TV cameras are showing Lampedusa to the world, but the world needs to understand that Lampedusa is not just about migrants, but is an island for tourists. I cannot let a humanitarian crisis destroy the island (Lambert, 2011).

The two facilities where migrants are detained on Lampedusa became seriously overcrowded and at times closed to new arrivals, due to the number of people who landed in 2011. Migrants, in turn, began squatting around the island; they slept at the port and on what came to be known as 'the hill of shame,' and wandered the streets of the small town. In June, arrivals reached new highs. During a twelve-hour period on 12 June, for example, 1,500 migrants arrived in seven boats (IRIN, 2011). The Guardia di Finanza, military personnel, employees of the Red Cross, and volunteers formed a human corridor at the port to receive and process the migrants.

Most people who arrived at this time were not on Lampedusa for long. Many were quickly removed and returned. Others were moved to other detention facilities on the larger island of Sicily. Many went to a large new centre in the remote town of Mineo, approximately one hour outside of Catania, Sicily. This centre holds some 2,000 migrants, which makes it the largest of its kind in Italy.

By the end of April, an estimated 26,000 migrants had landed on Lampedusa. The island was visited by national politicians (including then Italian Prime Minister Berlusconi), celebrities (such as Angelina Jolie, representing the UNHCR), and international NGOs. As one local participant in our research stated, 'Lampedusa was to become an outdoor prison,' a 'prison in the middle of the sea' (Interview, Sicily, June 2010). By the end of 2011, over 50,000 had landed on the island (Ministero dell'Interno, 2011).

The island became a hotly contested space. Residents fought at different times to block migrants from entering the port where they thought the national government had failed, and at other times they turned up at the local airport to demonstrate before visiting dignitaries, with placards stating that 'Lampedusa is not racist.'

\section{Detention facilities as islands}

During moments of relatively large 'spontaneous migrations' - when the scale and punctuated nature of mass movements of people exceed the capacity of states to respond - crises of state sovereignty (at the regional and state scale) and management are blatant. European states have responded to such moments of crisis with provisional construction and repurposing of military and civilian facilities on Malta, Lampedusa, and Greece. States also have turned to private agencies and citizens to share in the work of caring for, resettling, confining and expelling migrants. These ad hoc responses, in turn, have been formalized into policies that 
institutionalize detention as an infrastructure of crisis. Detention is one tool in a broader suite of policies designed to deter future migration.

Levy (2010) warns against conflating all facilities housing migrants and refugees as monolithic camps of exception. There are indeed differences among the legal purposes and material conditions of these facilities. Nonetheless, our research suggests the importance of understanding the range of migrant 'processing' facilities for temporary migrant care, confinement, resettlement and removal on islands. Recognizing these facilities as part of a complex archipelago of care and confinement reflects the scholarly literature on the ambiguous and shifting nature of detention (Gill, 2009). It also reflects the perspectives of several of our interviewees for whom the shifting terminology of Italian migrant facilities better reflects legal disputes and political expedience than fundamental changes in migration management or detention practice. One activist whom we interviewed recalled:

In 1998, Italy set up CPTs - Centri di Permanenza Temporanea - that now are Centri di Identificazione ed Espulsione (CIEs). ... Why that name? Because illegal immigration was not a crime as it is now. So they had to find a name that would justify an administrative detention. Migrants who were caught and taken into CPTs were subjected to administrative detention because they didn't commit any crime. However, this whole idea of administrative detention was conflicting enough with the notion of a state subject to the rule of law because, in a state subject to the rule of law, no one can be deprived of freedom if they haven't committed any crime. So, those centres were called 'Centres for Temporary Stay' where migrants might be confined up to sixty days (thirty days initially, later extended to sixty).

When the Turco-Napolitano Law - alas, both centre-left deputies - set up those places in 1998, the first CPT was in Trapani ... where it still is, in an old ... Art-Nouveau building that formerly was a ... rest home for the elderly. So, among other things, it was completely inadequate to be used as a prison, what actually CPTs were and CIEs are (Interview, Sicily, June 2010).

This quotation not only captures the institutionalization of ad hoc arrangements that repurpose idled state capacities: shifting from rest home to migrant centre; and welfarist to securitizing state (Walters, 2004). The speaker also addresses the tendency, across the political spectrum, to capture and enclose migrants in what the activist calls prisons and scholars have called 'carceral spaces' (Moran, Gill \& Conlon, 2013), regardless of formal institutional nomenclature (Andrijasevic, 2006).

Understanding detention as an infrastructure of normalized crisis also draws attention to the routinized incapacity of the state to detain people. While walls symbolize fortitude, as Brown (2010) argues, people repeatedly breach detention confines through escape, destruction, and sheer numbers. Despite investments in detention construction, EU states routinely do not have sufficient detention capacity to confine. Indeed, this is one of the fundamental crises of carceral institutions, leading to inevitable struggles over the terms and conditions of confinement. As one detention worker explained about Italian facilities, 
We went from about 200 beds in the old centre to 800 , although these figures were still below the actual number of people being housed ... So, in a time when migrants were flooding in, it's obviously difficult even to accommodate them on the national territory. (Interview, Sicily, June 2011).

Moreover, facilities are routinely not located in the places where refugees seek safe haven or where states are focusing interdiction and apprehension efforts (Mountz, Coddington, Catania et al., 2013). Indeed, the Return Directive adapted by the European Parliament in 2008, which allows member states to detain migrants for up to eighteen months, and the Dublin II agreement, which allows asylum claims only in the first country of entry, only amplified the problem (Karlsson, 2010; Schuster, 2011).

Border walls rise as material manifestations of boundary-making and also displace this crisis to prisons, multiplying rather than resolving crises of sovereignty. Rather than view the proliferation of private (humanitarian, non-profit, for profit) actors who are involved in the work of detention as a severing of sovereignty from the state, it is more useful to consider these as examples of the neoliberalization of state sovereignty through devolution and subcontracting. These extensions of sovereignty remain reliant on state legislation, funds, authority, and legitimation.

\section{Sovereignty and the body}

The sovereignty of the state, human agency, and materiality collide in the spaces of detention and migrant interdiction. Island spaces in particular mark state sovereignty through migration and territorial control. There, people's evasion of and resistance to programs of managing migration signal the limits, and hence persistent crises of, state sovereignty. This is often a violent collision between deeply unequal actors, and the effects materialize in bodily harm to and deaths of migrants.

Geopolitical squabbles between states over regional migration management have embodied effects. One poignant illustration is recounted by Bill Frelick in his Human Rights Watch report on the Pinar E dispute between Italy and Malta. Innocent, one of the migrants left stranded on a zodiac during this episode, recounted:

We were calling for people to rescue us. We waved our shirts to passing ships. Some passed us. Others gave us food and water, but did not rescue us. We had no fuel and the waves were carrying us. People were crying. We prayed to God to save us. . . After four days a big Turkish ship came and threw a rope to us. We climbed into the big boat. They gave us water to drink. They gave us food, even though it wasn't enough. We spent three more days on the Turkish boat (Frelick, 2009, p. 39).

Frelick notes (ibid.),

While Innocent expressed his heartfelt appreciation to Italy, the Italians nevertheless prolonged his suffering by four days while they argued with the Maltese to avoid taking him. 
The embodiment of geopolitics is also evident in state categorization and identification of people on the move as 'migrants,' 'refugees,' 'irregular,' and 'illegal.' Such governance categories are politically volatile and under persistent legal contest. Attempts to manage and categorize mobility and identify individuals through these terms reflect efforts to perfect bureaucracies of surveillance and biopolitical management. Far from neutral, these mechanisms track historic grooves of colonial and geopolitical subjecthood, acting as forms of administrative violence. A detention facility worker described the effective refoulements following Minister Maroni's so-called 'flows decree' and agreements with Libya and Tunisia:

[B]asically, they are returned to Libya even if they are Somalis or Nigerians. So it may happen that these people are coming from Somalia... The 'journey of hope,' as they say, doesn't entail only crossing the Mediterranean Sea from Libya to Lampedusa. Actually, the journey of hope is two years long because those who leave from Somalia have to cross the whole of Africa, through the desert, only to arrive in Libya and wait before they can leave. Then they leave, and once they have left, they are carried back again. You can see how that that's a sheer madness. But it's a matter of international politics and it's not up to me to discuss this issue (Interview, Lampedusa, June 2010).

Geopolitics shapes the spaces of asylum determination, which involve interviews and sometimes invasive medical examinations, which blend criminalizing logics of fraudulence and law-breaking and protective impulses of humanitarianism. Two participants in our research on Lampedusa discussed how X-rays of hands are used to estimate the age of migrants, and hence determine if they are eligible for protection as minors. One of them explains,

Unfortunately, the Red Cross guys will tell you, there's not always a perfect correspondence because our reference is the Western child. So that's a child who has a certain calcification of the bones depending on a certain diet, and that will be different from a child from Central Africa, or from East, or wherever ... (Interview, Lampedusa, June 2010).

Thus, not only are claims of national origin geopolitically charged in asylum determination, so too is age. While global inequalities of nutrition, shelter, and health care differentially grow into bones, medical technologies can mask geopolitical and economic divides (Fassin \& d'Halluin, 2005).

Such attempts to identify conflict sharply with the categorical erasure of the individual identities and histories of people who are on the move. An employee at the detention facility on Lampedusa whom we interviewed discussed the social and political invisibility of migrating people,

These people leave no mark, actually. Because they're nothing; they're ghosts. They are non-entities. In our system, they're nothing. And they are still nothing (Interview, Lampedusa, June 2010).

This 'fact,' in the worker's terms, of how migrants and refugees are represented, speaks to the ontologizing effects of state management practices. As Andrijasevic (2010, p. 157) writes, 
[such attempts at classification] signal the state's attempt to manage the multiplicity of movements, belongings and histories that characterize contemporary migrations in the Mediterranean region by symbolically reducing this heterogeneity to a single typology.

Tactics that migrants may use to move are severely constrained legally and economically, and state practices of deterrence increase vulnerabilities that migrants face in their efforts to create safety, freedom, and decent livelihoods. Indeed, embodied tactics are frequently the only remaining options. Migrants collectively defy detention's spaces of unfreedom by repeatedly burning detention facilities. They also protest captivity through hunger strikes and acts of selfharm. Sharing the news of these efforts is an important aspect of the networks (online and offline) that migrants and their supporters have created (Coddington, Catania, Mitchell-Eaton, et al., 2012).

Political invisibility and material deaths and disappearances of migrants foster one another. In the geopolitics of human vulnerability, suggests Butler (2009), the politics of visibility and recognition are paramount. Unmourned, uncontested dehumanization and disappearance reproduce an inhuman political field that blames migrants as the cause of crises while obscuring how violent state policies and practices create the conditions for and acts of migrant harm (cf. Nevins, 2003).

Migrant organizations and groups working in solidarity with them remember and use acts of memorialization to make visible the violence of state sovereignty. For a priest with whom we spoke, holding funerals for people is a basic act of spiritual recognition,

If they're professed Christians, we give them a Christian burial ... The important thing is that they are Christians. But if they're Muslims, which has never happened so far, it would be advisable to allow a Muslim to lead the prayer (Interview, Lampedusa, June 2010).

For others, memorialization is also more explicitly political. In August 2011, for example, the anti-racist network Welcome to Europe built a memorial in Tychero, Greece to remember the deaths of migrants in the Evros region specifically and to recognize events along European borders more generally. The memorial was meant to 'give back a piece of dignity' to 'those whose death[s] disappeared,' to 'those who survived,' and to 'all of us, who feel ashamed in the moment of these deaths because we failed in our attempt to stop this murderous [border] regime and to create a welcoming Europe' (Welcome to Europe, 2011).

These acts are deeply personal commemorations that attempt to 'create a space for all those who lost their lives' in a 'place of failure and loss.' 'Remembering here, means to save the stories of the uncounted faces of those who died at the borders of Europe' (Welcome to Europe, 2011). Such intimate acts of love and loss simultaneously work to constitute networks of family, community, and solidarity that traverse EU and other border regimes. The media (including social media) are crucial to remembering the dead and creating visible networks of resistance that transcend the layers of sovereign containment and deterrence at a range of geographic scales.

The construction of temporary gathering sites and living spaces among migrant networks also represent embodied forms of resistance to sovereign power and its territorial work of containment and border-policing. They are sites of self-organization and mutual 
responsibility that Butler (2009) regards as imperative in challenging the geopolitics of the invisible inhuman. To that end, and echoing Andrijasevic (2010, pp. 161-162),

What is at stake is a theoretical and political challenge to recognise migration as a constituent force in the production of the European polity and citizenship.

To date, efforts to include migrants in formulations of European citizenship remain largely symbolic. After the 2013 deaths off the coast of Lampedusa, Italy granted posthumous citizenship to those who had died, but faced criticism for detaining and deporting survivors (de Haas, 2013b).

\section{Conclusion}

Migration management lies at the core of the geopolitics of migration, wherein various national and supranational parties negotiate responses to migration in the form of management. Over the past thirty years, the regional scale has been created as a potential means of regulating human mobility, due to the inability of individual nation states to control migration. This paper has shown the significance of the multiply-scaled struggle over sovereignty and territoriality in geopoliticized fields of migration, viewed through the spatial lens and migration struggles on islands. The deadly effects of this regional migration management regime continue to be obscured and shifted to those who suffer its consequences. The 2013 capsizing of a boat filled with asylum seekers from Africa led to over 350 deaths (BBC News Europe, 2013). The media response followed a well-worn narrative: reports of beleaguered Frontex agents, unable to patrol such vast waters; wily and exploitative human smugglers. Questions about what could be done to prevent such tragedies, thus, tended to reinforce a securitized border, rather than create legal avenues for entry and long-term strategies for economic self-determination (de Haas, 2013a).

The inability of states to prevent and constrain human mobility is obvious during times of mass migration or with innovative attempts at entry. At these high-profile moments, migrant facilities and entire islands or ports of entry cannot physically contain humans assembled there. The policies and practical responses to these events have normalized detention as part of the landscape of asylum seeking and migration. The institutionalization of migrant detention, in turn, may be understood as an infrastructure of extended, normalized crisis (Agamben, 1998; Mountz, 2010). That is, states routinely struggle with a disjuncture between detention capacity and policing practices: spatial mismatches between the locations where migrants are apprehended and the existence of infrastructure with which to process and/or detain them.

We have also explored how migrants exercise mobility in ways that prove fundamental to the shape that sovereignty takes. Struggles over sovereign and migrant power thus constitute the institutionalized terrain of sovereignty, at regional borders, island ports, and migrant facilities. Whether these become safe havens or open-air prisons is a measure of geopolitical power, with the body serving as a site where sovereignty is contested. This attention to migrant agency sheds additional light on the crisis of sovereignty that border walls represent.

These crises can be seen in walls at different scales. Islands are places where state control over territory intersects with the international law of the sea, international human rights obligations, and intra- and interregional conflicts. On islands, the materiality of human mobility encounters geographical imaginations of control. In the case of Lampedusa, the island 
is simultaneously a place of settlement, tourist destination, militarized outpost, migrant prison for Italy and the broader EU community, and unwittingly a research site for such practices. The island becomes a place where these land uses often clash, where local residents contest their perceived neocolonial status within Italy, and where physical proximity as a safe haven for distressed boats in international waters has been trumped by Berlusconi's declaration of the port's unsuitability.

Detention also functions as an infrastructure of crisis in ways that are both material, in terms of facilities and resources, and political. State sovereignty works not only through the political will to detain, but also by means of the actual practices of detention, which require facilities, personnel, logistical plans, and means of transportation. Attention to the materiality of state sovereignty at the scale of detention facilities and the detention archipelago highlight the repeated disjuncture between policy and practice. As states have attempted to expand and upgrade spaces for detention, reception, and exclusion, they face constraints of budgets, political will, and opposition. These constraints limit states' ability to infinitely expand capacity and site facilities. That is, the legal, political, and geographic contingency of detention facilities speaks to the recurrent failure of detention as a sovereign means of managing migration.

Migrants enter into limbo in these geopolitical spaces between states where struggles over legality, safety, and border enforcement unfold. The examples detailed in this paper engender new and larger questions about clashing visions of how to resolve these power struggles. Migrants and groups working in solidarity with them can be understood both in relation to and against the frames of the state. Both 'strategies' of action and collective power pose significant challenges to state sovereignty and usher in further crises of state sovereignty.

To that end, management and regional migration regimes are the latest institutionalized attempts to shore up sovereignty. Territorializing sovereignty at the national scale, however, does not solve crises of state sovereignty or provide additional avenues for pursuit of human rights, but amplifies crises of state sovereignty. Migration management and regional solutions paper over systemic crises of sovereignty, and regional, geopolitical contests. There is an assumption in the discourse and practice of migration management that state sovereignty is functional, or that its failings may be made good through reconfiguration (including outsourcing). Yet, this assumption treats migration as a problem, masking issues of human rights and exercises of migrant agency, whether in the name of freedom of movement, selfdetermination, or traditional practice. The discursive and practical construction of the region as a governance and geopolitical tool, then, simultaneously masks histories of colonial and geoeconomic rule and their more recent formations.

Migration foregrounds the stakes of what Fraser (2009) calls the 'meta-political injustice' of national scale political spaces wherein migrants are legally and practically excluded from residence and formal decision-making. But with such a transnational issue, democratic frame-setting must still find a means of challenging the territoriality of sovereignty and citizenship as exemplified by the walls of borders and detention facilities. Brown's (2010) reading of walls, and by extension detention facilities, as manifestations of failed sovereignty offers political promise. Migrant and ally networks that cross the walls of borders and detention centres consistently expose the limits of state sovereignty and create new forms of political power. However, because states rely on violent practices to resolve crises of state sovereignty, ending this form of state violence poses challenges for contemporary politics in the EU, the Mediterranean, and beyond. 


\section{Acknowledgements}

This material is based upon work supported by the National Science Foundation (NSF) under Award \#0847133. Any opinions, findings, and conclusions or recommendations expressed in this material are those of the authors and do not necessarily reflect the views of the NSF. The authors thank research assistant Tina Catania for her work in the field and the many participants in our research. We also thank Nathalie Bernardie-Tahir and Camille Scholl for their editorial and organizational work on this special thematic section.

\section{References}

Agamben, G. (1998). Homo sacer: Sovereign power and bare life. Stanford CA: Stanford University Press.

Agnew, J. (1994). The territorial trap: the geographical assumptions of international relations theory. Review of International Political Economy, 1(1), pp. 53-80.

Andrijasevic, R. (2006). Lampedusa in focus: migrants caught between the Libyan desert and the deep sea. Feminist Review, 82(1), pp. 120-125.

Andrijasevic, R. (2010). From exception to excess: detention and deportations across the Mediterranean space. In N. De Genova \& N. Peutz (Eds.) The deportation regime: Sovereignty, space and the freedom of movement (pp. 147-165). Durham NC: Duke University Press.

Arendt, H. (1951). The origins of totalitarianism. New York: Schocken Books.

Baldacchino, G., \& Milne, D. (2006). Exploring sub-national island jurisdictions: an editorial introduction. The Round Table: Commonwealth Journal of International Affairs, 95(386), pp. 487-502.

BBC News Europe (2013). Mediterranean 'a cemetery' - Maltese PM Muscat. 12 October. Retrieved from: http://www.bbc.co.uk/news/world-europe-24502279.

Beck, U. (2006). The cosmopolitan vision. Cambridge, UK: Polity Press.

Bejarano, C., Morales, C.M., \& Saddiki, S. (2012). Understanding conquest through a border lens: a comparative analysis of the Mexico-U.S. and Morocco-Spain regions. In J.M. Loyd, M. Mitchelson \& A. Burridge (Eds.) Beyond walls and cages: Prisons, borders, and global crisis (pp. 27-41). Athens GA: University of Georgia Press.

Betts, A. (ed.) (2010). Global migration governance. Oxford, UK: Oxford University Press.

Bialasiewicz, L., Dahlman, C., Apuzzo, G. M., Ciuta, F., Jones, A., Rumford, C., Wodak, R., Anderson, J. \& Ingram, A. (2009). Interventions in the new political geographies of the European 'neighbourhood'. Political Geography, 28(2), pp. 79-89.

Bigo, D. (2002). Security and immigration: toward a critique of the governmentality of unease. Alternatives, 27(special issue), pp. 63-92.

Bosniak, L. (2000). Citizenship denationalized. Indiana Journal of Global Legal Studies, 7(2), pp. 447-509. 
Brown, W. (2010). Walled states, waning sovereignty. New York: Zone Books.

Butler, J. (2009). Frames of war. London: Verso.

Carling, J. (2007). Unauthorized migration from Africa to Spain. International Migration 45(4), pp. 3-37.

Carr, M. (2012). Fortress Europe: Dispatches from a gated continent. New York: New Press.

Castells, M. (1996). The rise of the network society (vol. 1). Oxford: Wiley-Blackwell.

Coddington, K., Catania, R.T., Mitchell-Eaton, E., Loyd, J., \& Mountz, A. (2012). Embodied possibilities, sovereign geographies, and island detention: negotiating the 'right to have rights' on Guam, Lampedusa and Christmas Island. Shima: International Journal of Research into Island Cultures, 6(2), pp. 27-48.

Cole, M. (2011). Tunisia migrants: Italy puts Europe on alert. BBC, 15 February. Retrieved from: http://www.bbc.co.uk/news/world-europe-12461866

Cuttitta, P. (2009). The Mediterranean Grenzsaum: migration controls and borders in the Strait of Sicily. Conference presentation. BORDERSCAPES II. Trapani, Italy.

Dear, M. (2013). Why walls won't work: Repairing the US-Mexico divide. Oxford: Oxford University Press.

De Haas, H. (2013a). Smuggling is a reaction to border controls, not the cause of migration. Hein de Haas blog. October 5. Retrieved from http://heindehaas.blogspot.com/2013/10/smuggling-is-reaction-to-border.html

De Haas, H. (2013b). Lampedusa: only the dead can stay. Hein de Haas blog. October 8. Retrieved from http://heindehaas.blogspot.com/2013/10/lampedusa-only-dead-canstay.html

Elden, S. (2009). Terror and territory: The spatial extent of sovereignty. Minneapolis MN: University of Minnesota Press.

Fassin, D., \& D'Halluin, E. (2005). The truth from the body: medical certificates as ultimate evidence for asylum seekers. American Anthropologist, 107(4), pp. 597-608.

Fraser, N. (2009). Scales of justice: Reimagining political space in a globalizing world. New York: Columbia University Press.

Frelick, B. (2009). Pushed back, pushed around: Italy's forced return of boat migrants and asylum seekers, Libya's mistreatment of migrants and asylum seekers. New York: Human Rights Watch.

Geiger, M., \& Pécoud, A. (Eds.) (2010). The politics of international migration management. New York: Palgrave Macmillan.

Gill, N. (2009). Governmental mobility: the power effects of the movement of detained asylum seekers around Britain's detention estate. Political Geography, 28(3), pp. 186-196.

Global Detention Project. (2012). Italy detention profile. Global Detention Project. Retrieved from http://www.globaldetentionproject.org/countries/europe/italy/introduction.html

Goodwin-Gill, G. S. (2011). Opinion: the right to seek asylum: interception at sea and the principle of non-refoulement. International Journal of Refugee Law, 23(3), pp. 443457. 
Hall, S., Critcher, C., Jefferson, T., Clarke, J., \& Roberts, B. (2013). Policing the crisis: mugging, the state and law and order. Basingstoke: Palgrave Macmillan.

Herod, A. (2011). Scale. London: Routledge.

Hiemstra, N. (2013). 'You don't even know where you are': chaotic geographies of US migrant detention and deportation. In D. Moran, N. Gill \& D. Conlon (Eds.) Carceral spaces: Mobility and agency in imprisonment and migrant detention (pp. 57-75). Aldershot, UK: Ashgate.

Human Rights Watch. (2011). The EU's dirty hands: Frontex involvement in ill-treatment of migrant detainees in Greece. New York: Human Rights Watch.

Hyndman, J. (2012). The geopolitics of migration and mobility. Geopolitics, 17(2), pp. 243255.

Hyndman, J. (2008). Conflict, citizenship and human security: geographies of protection. In D. Cowen \& E. Gilbert (eds) War, citizenship, territory (pp. 241-257). New York: Routledge.

Hyndman, J., \& Giles, W. (2011). Waiting for what? The feminization of asylum in protracted situations. Gender, Place \& Culture, 18(3), pp. 361-379.

IRIN. (2011). Libya-Italy: by boat to Lampedusa and a new life. Retrieved from http://www.irinnews.org/report/92993/libya-italy-by-boat-to-lampedusa-and-a-new-life

Island Detention Project (2014). http://www.islanddetentionproject.org

Karlsson S. (2010). The fate of the paperless. Retrieved from http:/www.policyinnovations.org/ideas/commentary/data/000186

Klein, N. (2003). The rise of the fortress continent. The Nation, 3 February. Retrieved from http://www.thenation.com/article/rise-fortress-continent\#

Klepp, S. (2010). A contested asylum system: the EU between refugee protection and border control in the Mediterranean Sea. European Journal of Migration and Law, 12(1), pp. $1-21$.

Koser, K. (2010). Introduction: international migration and global governance. Global Governance, 16(3), pp. 301-315.

Kothari, U., \& Wilkinson, R. (2010) Colonial imaginaries and postcolonial transformations: exiles, bases, beaches. Third World Quarterly, 31(8), pp. 1395-1412.

Lambert, O. (2011). Italy's Lampedusa left in crisis after Arab Spring. $B B C$. 14 June. Retrieved from http://www.bbc.co.uk/news/world-europe-13747558

Levy, C. (2010). Refugees, Europe, camps/states of exception: 'into the zone', the European Union and extraterritorial processing of migrants, refugees and asylum-seekers (theories and practice). Refugee Survey Quarterly, 29(1), pp. 92-119.

Mainwaring, C. (2012). Resisting distalization? Malta and Cyprus' influence on EU migration and asylum policies. Refugee Studies Quarterly, 31(4), pp. 38-66.

Marr, D. (2009). The Indonesian solution: Christmas Island. The Monthly, 49(September): 115. Retrieved from http://www.themonthly.com.au/monthly-essays-david-marr-indianocean-solution-christmas-island-1940 
Marston, S. (2000). The social construction of scale. Progress in Human Geography, 24(2), pp. 219-242.

Ministero dell'Interno. (2011). Informativa al Senato sui flussi migratori a Lampedusa. Il sottosegretario Viale: 'L'emergenza che stiamo gestendo coinvolge tutta l'Europa; bisogna comprendere ciò se vogliamo un unico grande sistema di governo del fenomeno dell'immigrazione". Retrieved from www.interno.it/mininterno/export/sites/default/it/sezioni/sala stampa/notizie/immigrazi one/0000070 20110929 informativa Viale al Senato.html

Moran, D., Gill, N., \& Conlon, D. (eds) (2013). Carceral spaces: Mobility and agency in imprisonment and migrant detention. Aldershot: Ashgate.

Mountz, A. (2010). Seeking asylum: Human smuggling and bureaucracy at the border. Minneapolis MN: University of Minnesota Press.

Mountz, A. (2011). The enforcement archipelago: detention, haunting, and asylum on islands. Political Geography, 30(3), pp. 118-128.

Mountz, A., Coddington, K., Catania, R., \& Loyd, J. M. (2013). Conceptualizing detention: mobility, containment, bordering, and exclusion. Progress in Human Geography, 37(4), pp. 522-541.

Mountz, A., \& Loyd, J. M. (forthcoming). Constructing the Mediterranean region: obscuring violence in the bordering of Europe's migration "crises." $A C M E$.

M.S.S. v. Belgium and Greece. (2011) European Court of Human Rights. Retrieved from: http://hudoc.echr.coe.int/sites/eng/pages/search.aspx?i=001-103050

Nevins, J. (2003). Thinking out of bounds: A critical analysis of academic and human rights writings on migrant deaths in the US-Mexico border region. Migraciones Internacionales, 2(2), pp. 171-190.

Said, E. (1978). Orientalism. New York: Pantheon Books.

Schuster L. (2011). Dublin II and Eurodac: examining the (un)intended(?) consequences. Gender, Place and Culture, 18(3), pp. 401-416.

Silvey, R. (2004). Power, difference and mobility: feminist advances in migration studies. Progress in Human Geography, 28(4), pp. 1-17.

Triandafyllidou, A. (2014). Multi-levelling and externalizing migration and asylum: lessons from the southern European islands. Island Studies Journal, 9(1), pp. 7-22.

van Houtum, H. (2010). Human blacklisting: the global apartheid of the EU's external border regime. Environment and Planning D: Society and Space, 28(6), pp. 957-976.

Walters, W. (2004). Secure borders, safe haven, domopolitics. Citizenship Studies, 8(3), pp. 237-260 .

Walters, W. (2008). Bordering the sea: shipping industries and the policing of stowaways. Borderlands, 7(3), pp. 1-25. 
Wimmer, A. \& Glick-Schiller, N. (2002). Methodological nationalism and beyond: nation-state building, migration, and the social sciences. Global Networks, 2(4), pp. 301-334.

Welcome to Europe. (2011). Giving back names and dignity to lost migrants. Welcome to Europe. Retrieved from http://w2eu.net/2011/09/01/giving-back-names-and-dignity-tolost-migrants/ 